\title{
THE INFLUENCE OF FIXED-ROUTE TAXI ON ROAD ACCIDENTS AND AIR POLLUTION
}

\author{
Jury Komarov, Vitali Fedotov \\ Volgograd State Technical University, Department of Automobile Transport, \\ 28 Lenin av. 400131 Volgograd, Russia.E-mail: fat@vstu.ru
}

Received 20 November 2005; accepted 4 January 2006

\begin{abstract}
The development of market economy in Russia expands the need for movement of groups of people of large mega cities on time to a place at simultaneous reduction of the number of groups with identical purposes. Therefore for many cities a wide use of fixed-route taxis the service of passengers at a constant increase of the numbers of routes and the numbers of transport units was characteristic. At the certain intensity of the movement of fixed-route taxis on separate sites of city highways the transport stream and the changing quality of environment raises the risk of road accident and becomes ecologically unsafe. The results of the estimation of the negative influence of fixed-route taxis in comparison with other categories of vehicles are presented. The research was made on city highways running through the zones with a greater number of cultural and community places, shopping centers and administrative establishments. Perspective ways of the increase of traffic safety and the decrease of concentration of harmful emissions are offered.
\end{abstract}

Keywords: fixed-route taxis, a transport stream, risk of road accident, emissions of toxic gases and fine disperse particles, engineering methods of decrease in concentration of harmful substances, increase of safety of traffic.

\section{Introduction}

The confident development of market economy of the country expands the need for movement of groups of the population of large mega cities on time to a place at simultaneous reduction of the number of groups with the identical purposes. At the absence of a significant part of citizens' personal vehicles greater passenger streams are formed in the zones of shopping centers, stations, educational establishments, office buildings and other objects. Therefore for many cities of Russia a wide use of fixed-route taxis for the service of passengers was characteristic at a constant increase of the numbers of routes and the numbers of transport units.

\section{Influence of fixed-route taxis on the quality of trans- portation and environment}

Routing taxi transportations provide a rational combination of the convenience and peculiar taxi with profitability of transportation in bus service. Simultaneous service of a small group of people makes a trip more comfortable (in a minibus only landing places), allows to consider partially individual requirements of passengers (the stop on demand) to raise the speed of the message and considerably to reduce (in comparison with a taxi) the cost of a trip.
At the constancy of a line of a route and its terminal points intermediate stops can not be fixed and made on demand of passengers. All this promotes the reduction of the time of arrival of passengers to stops and to the destination. Movement routing of fixedroute taxis is carried out with rather high periodicity that reduces the waiting time for passengers of a vehicle at a stop. A plenty of various routes covering even the most remote areas and directions, without transport communication, allows passengers to choose the most convenient route that reduces time of a trip and relieves the necessity to make changes.

The greatest interest for commercial motor transportation is represented by highways running through the zones with a greater number of cultural and community places, shopping centers and administrative establishments. The volume of passenger traffic in such areas remains constant within a day. The growth of the number of carriers and the volume of transportations increases the intensity of movement that leads to the increase of transport delays, the raised charge of fuel and the accelerated wear process of units and units of vehicles. The urban population participating in traffic is subjected to failure, the influence of gases, microscopic particles of deterioration of trunks and parts of machines. 
At the certain intensity of movement of fixedroute taxis in separate sites of city highways the transport stream changes the quality of environment, raises the risk of failures and becomes ecologically unsafe.

\section{Research into the influence of fixed-route taxis on the level of failures and conditions of environment}

The Faculty of Automobile transport with the participation of students of the Organization and traffic safety on the basic highways of Volgograd made long-term research into characteristics of transport streams, modes of movement of routing transport, durability of details of the maintenance service providing safety requirements in operation.

A special attention was given to the city routes running through the sites with raised frequency crossing of transport and pedestrian streams. By control (selective) inspections it has been revealed that $2,5 \mathrm{~km}$ in the center of Volgograd Lenin street is a zone of the greatest volume of passenger traffic and intensity of a transport stream. Three bus and five trolleybus routes, 46 routes of minibuses, fixed-route taxis, including 32 routes - transit pass through the abovestated site of the highway. Individual motor transport participates in the transportations of passengers. The highway has three lanes in each direction separated by green plantings (trees and bushes) up to $30 \mathrm{~m}$. wide.

In earlier published results of the research it is shown [1], that in 2002 in this site of the highway the intensity of cars of one direction did not exceed $790 \mathrm{veh} / \mathrm{h}$, minibuses $320 \mathrm{veh} / \mathrm{h}$, trolley buses $56 \mathrm{veh} / \mathrm{h}$, buses $5 \mathrm{veh} / \mathrm{h}$ a day. The stream of ground transport had the maximal values up till $2 \mathrm{pm}$ and gradually decreased till 6 pm 1,5 times and till 9 pm 4 times.

In 2003, 2004 at the preservation of the general picture of the intensity of movement in the afternoon the intensity of cars increased up to $890 \mathrm{veh} / \mathrm{h}$, "Route taxi" up to 380-420 veh/h the intensity of public passenger transport has not changed. In 2005 the growth of the intensity of movement has proceeded: car intensity has reached $1250 \mathrm{veh} / \mathrm{h}$, "Route taxi" - $600 \mathrm{veh} / \mathrm{h}$. The intensity of a transport stream began to come nearer to throughput of a highway and in such days the decrease in the intensity of movement of trolley buses is noted to $50-52 \mathrm{veh} / \mathrm{h}$.

In the afternoon site columned movement is characteristic, maneuver is complicated because of high density of a transport stream $(80 \mathrm{veh} / \mathrm{km})$, a plenty of crossroads and pedestrian crossings (quantity of stops of individual transport 4-6, Route taxi 8-11; average waiting time 20-30 with; average speed of the vehicles does not exceed 16-20 km/h, and of trolley buses $10-14 \mathrm{~km} / \mathrm{h}$ ).
Table 1. Modes of movement of cars in a transport stream, \%

\begin{tabular}{|l|c|c|c|c|}
\hline $\begin{array}{c}\text { Vehicles } \\
\text { Dispersal }\end{array}$ & Speeding & Braking & $\begin{array}{c}\text { Constant } \\
\text { speed }\end{array}$ & Idling \\
\hline $\begin{array}{l}\text { "Route } \\
\text { taxi" }\end{array}$ & 31,1 & 26,2 & 17,5 & 25,2 \\
\hline $\begin{array}{l}\text { Individual } \\
\text { transport }\end{array}$ & 228 & 15,9 & 31,3 & 309 \\
\hline $\begin{array}{l}\text { Buses, } \\
\text { trolleybuses }\end{array}$ & 18,5 & 12,8 & 292 & 39,5 \\
\hline
\end{tabular}

At the same time, the character of movement of "Route taxi" and other kinds of motor transport in a transport stream considerably differs (Table 1). More maneuverable individual cars and "Route taxi", borrowing three lanes, reduce carrying, as a consequence, simultaneous by increasing the risk of road accidents.

According to the data of statistical service of Volgograd in six months of 200439 road accidents were accomplished with the participation of drivers of passenger transport. In comparison with the similar period of 2003 the growth has made $25 \%$ [2]. The growth of failures with the participation of "Route taxi" proceeds in current year: in the first half of the year there were 34 failures in passenger transport, as well as in the past, not less than $70 \%$ of failures occurred with the participation of drivers of "Route taxi" (Fig).

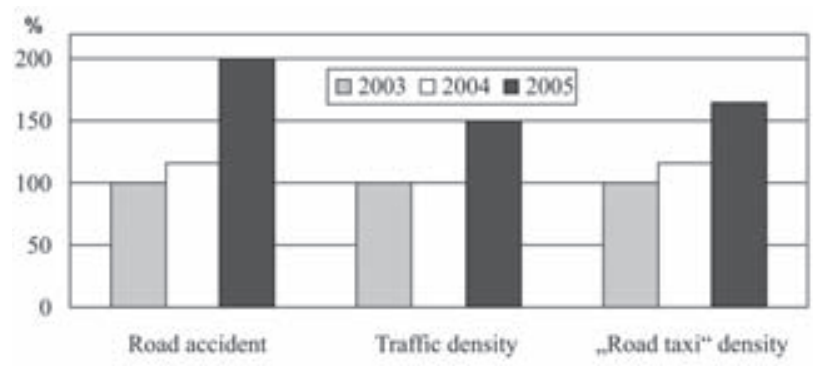

Fig. Statistical data

The variable mode of movement, frequent stops and congestions of cars on crossroads are the reasons of the raised pollution. The results before the research executed by the authors and calculations on ecologically unsafe sites of Lenin av. from Krasnoznamenskaja st. up to Lenin square [3] have shown: at the intensity of adjustable movement $420-600 \mathrm{veh} / \mathrm{h}$ on a strip (30$40 \%$ fixed-route taxi) emissions of the basic components of gases $-\mathrm{CO}, \mathrm{CnHm}$, NOx on highways with 2-3 strips in each direction can be within the limits of, accordingly: $72,7-90,8 \mathrm{~kg} / \mathrm{km} \mathrm{h} ; 5,2-6,6 \mathrm{~kg} / \mathrm{km} \mathrm{h}$; $10,4-13,0 \mathrm{~kg} / \mathrm{km} \mathrm{h}$. Thus up to $50 \%$ of volumes are emissions of the fulfilled gases of "Route taxi". Control measurements (during the year period at day time) have shown that average values of the concentration 
of air pollution main buildings (average 7-12; density buildings of 70-80\%, presence of green plantings) and usual speed of a wind of $2-5 \mathrm{~km} / \mathrm{s}$ (at edge of a highway at height from 0,5 up to $4 \mathrm{~m}$, accordingly, $8,7-2,6 \mathrm{mg} / \mathrm{m}^{3}$.

The prevalence of the unsteady modes of movement of routing transport considerably influences the durability of details and units of cars. Most typically it is seen on the service life of wearing out of details, for example: brake parts, trunks.

During control operation 10 fixed-route taxis were fixed as reasons of failure and before the replacement of brake parts the measurements of height of a protector of trunks were carried out. The residual thickness of a frictional layer was measured on replaced parts.

The analysis of the results of control operation has shown that replacements of braking parts in forward brake mechanisms of fixed-route taxis (irrespective of the manufacturer) were carried out from 10.000 up to $16.000 \mathrm{~km}$. Average run was $13.200 \mathrm{~km}$. The resource of lobbies brake parts manufactures of Joint stock company "VATI", calculated in view of correlation dependence of residual thickness of a frictional layer on run (up to thickness of a frictional layer of 3 $\mathrm{mm}$ according to the Operation manual on cars) has made $14800 \mathrm{~km}$. Braking parts owing to the decrease of efficiency of braking were replaced at intervals between TO-1 and TO-2, instead of technical service at which the next scheduled check of parts is stipulated by the manufacturer of a vehicle and, if necessary, their replacement.

Changes of a protector on height (deterioration) have been fixed for run "Route taxi" within a month $(6000-8000 \mathrm{~km})$. Run of trunks of under control taxi was at an interval of 15-90 thousand of km. Measurements of a protector of trunks have not revealed the catastrophic rate of the reduction of height of a protector that allowed to assume that the process of wear in the above-stated interval of run is in a zone of normal deterioration and can be approximated by linear dependence. Processing of statistical data make certain of average deterioration of a protector of forward trunks of $0,08 \mathrm{~mm}$ on $1000 \mathrm{~km}$ of run and average run of trunks 92,6 thousand of km up to minimally admissible value of height of a protector $(2 \mathrm{~mm}$ for buses of the national standard - ГОСТ Р 51709-2002). Trunks VORONEZH - run 125 thousand of km appeared the most durable in observable conditions of operation.

Owing to wiping trunks of wheels and a road covering (at coupling with road), and also brake parts (at braking) the transport stream creates the cloud of dust consisting of more than $60 \%$ of microscopic and ultramicroscopic particles in radius of $10,0-0,25$ microns and less. The time of natural coagulation and the division of particles with these sizes is defined by tens of hours and can be compared in due course with distributions of gaseous components [4].

The basic volume of the dust formed by transport streams is made of particles of an asphalt road covering with which, according to [5], the layer up to $1 \mathrm{~mm}$ a year is erased.

The calculation of the underestimated estimations of the volume of dust (without taking into account the particles of deterioration of back brake parts and trunks of back wheels) in the above-stated Lenin street in view of intensity of movement and the sizes of a road cloth has shown that on trunks and parts the dust is up to $20 \%$ of total amount (trunks dust of $0,098-0,112 \mathrm{~kg} / \mathrm{km} \mathrm{h}$, particles of brake overlays of $0,038-0,044 \mathrm{~kg} / \mathrm{km} \mathrm{h}$.

The estimations of the volumes of particles of deterioration brake parts and the trunks created by "Route taxi" and individual transport (for example the car "Volga 31029 ") in view of key parameters of their modes of braking are resulted in Table 2. Calculations of the intensity of a wear process were done according to the formulas recommended in [6] and [7].

Table 2. Modes of braking and volumes of particles of deterioration brake parts and trunks

\begin{tabular}{|c|c|c|c|c|c|}
\hline \multirow{2}{*}{$\begin{array}{l}\text { Vehicles } \\
\text { Dispersal }\end{array}$} & \multicolumn{3}{|c|}{$\begin{array}{l}\text { The parameters of braking } \\
\text { led } 1 \mathrm{~km} \text { of a route }\end{array}$} & \multicolumn{2}{|c|}{$\begin{array}{l}\text { Particles of } \\
\text { deterioration brake } \\
\text { parts and trunks, } \\
\mathrm{g} / 1000 \mathrm{~km}\end{array}$} \\
\hline & $\begin{array}{l}\text { first } \\
\text { speed } \\
\text { (before } \\
\text { stop) }\end{array}$ & $\begin{array}{l}\text { braking } \\
\text { moment }\end{array}$ & $\begin{array}{l}\text { amount of } \\
\text { braking } \\
\text { before } \\
\text { stop }\end{array}$ & $\begin{array}{l}\text { from } \\
\text { wiping } \\
\text { ahead } \\
\text { braking } \\
\text { parts }\end{array}$ & $\begin{array}{l}\text { from } \\
\text { wiping } \\
\text { ahead } \\
\text { trunks }\end{array}$ \\
\hline "Gazels & 37,0 & 240,0 & 11 & 44,1 & 144,4 \\
\hline $\begin{array}{l}\text { "Volga } \\
31029 "\end{array}$ & 39,3 & 130,0 & 4 & 30,0 & 61,2 \\
\hline
\end{tabular}

The note: at calculation on the complete set of lobbies parts, counting upon two forward wheels

Control measurements of the concentration of firm particles on the above-stated site and at the edge of the highway at the height of 0,5-2 $\mathrm{m}$ (for the same conditions) have shown that general concentration of firm particles makes $0,24-1,41 \mathrm{mg} / \mathrm{m}^{3}$, concentration of firm particles in the sizes less than 10 microns of $0,14-0,48 \mathrm{mg} / \mathrm{m}^{3}$. 


\section{Conclusions}

Thus, "Route taxi" heavy use in a zone of the greatest volume of passenger traffic reduces the efficiency of transport system, promotes the growth of risk of road accidents and breaks ecology.

Municipal formations promoting the expansion of the volume of given and sold transport services of new quality should decrease the probability of the risks menacing to safety and health and operate a technological process of execution of these services. When the process of movement on streets parallel to the basic highway will be organized, it is possible to create the transport system combining high efficiency of motor transport with the minimal influence on environment.

\section{References}

1. Dobrovolsky, S. V.; Komarov, U. A.; Kotov, E. V.; Fedotov, V. N. Century of emissions VV on an operating network of routes of municipal motor-vehicle transport at preservation of transit volume of passenger traffic. In: Materials of the international scientific conference "Progress of vehicles and systems (Материалы международной научной конференции "Прогресс транспортных средств и систем"). Volgograd, 2002, p. 82-83 (in Russian).

2. Kraschenko, A. Will be work. Magazine of the boss (Журнал руководителя - BUSINESS) No 7, 2004, p. 8-9 (in Russian).

3. Komarov, U. A.; Rysakov, A. A.; Fedotov, V. N. The technology of the cleaning the air from pollution of moving transport. VSTU. A series "Transport ground systems" (Изв. ВолгГТУ. Серия «Транспортные наземные системы), No 1, 2004, p. 113-118 (in Russian).

4. Kiselyov, N. D. Cleaning of air from high disperse dust by the method of artificial ionization (Очистка воздуха от высокодисперсной пыли методом искусственной ионизации). Moscow: Mechanical engineering, 1966.71 p. (in Russian).

5. Motague, P. Tire dust. Rachel's Environment \& health Weekly, 1995, No 439 (April 27).

6. Kragelskij, I., etc. Bases of calculations of friction and deterioration (Основы расчетов на трение и износ). Moscow: Mechanical engineering, 1977. 526 p. (in Russian).

7. Tarnovskij, V. N.; Gudkov, V. A.; Trethakov, O. B. Auto trunks (Автомобильные шины). Moscow: Transport, 1990. 217 p. (in Russian). 